\title{
Resource use efficiency of cotton in improved vs conventional planting geometry with exogenous application of bio-stimulant and synthetic growth retardant
}

\author{
N. Hussain ${ }^{a}$ A. Anwar ${ }^{\text {(D) }, A . Y_{\text {Yasmeen }}^{a} \text { (D), M. Arifa* (D), S. Naz }}$ (D), M. Bibib (D), J. Iqbal (D),

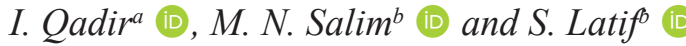 \\ ${ }^{a}$ Bahauddin Zakariya University, Multan, Pakistan \\ bPir Mehr Ali Shah Arid Agriculture University, Rawalpindi, Pakistan \\ 'Department of Agronomy, The Islamia University of Bahawalpur, Bahawalpur, Punjab, Pakistan \\ *email: jamarif@gmail.com
}

Received: September 12, 2018 - Accepted: October 17, 2019 - Distributed: February 28, 2021

(With 6 figures)

\begin{abstract}
Plant growth regulators and improved planting density are the innovative techniques in the establishment of more productive cotton crop. A field study was planned to assess the role of growth regulators in the resource utilization efficiency of cotton cultivars under different row spacing at Agronomic Research Area, Bahauddin Zakariya University Multan and Usmania Agricultural Farm, Shujaabad during Kharif 2012. The study was comprised of cotton cultivars viz. CIM-573 and CIM-598, cultivated under conventional $(75 \mathrm{~cm})$, medium $(50 \mathrm{~cm})$ and improved ultra-narrow row spacing $(25 \mathrm{~cm})$ and foliar spray of growth regulators viz. moringa leaf extract (MLE) and mepiquat chloride (MC), either alone or in combination, distilled water as a control. The application of MLE alone and in combination (MLE + MC) showed the promoting effect on crop growth rate, net assimilation rate, leaf area index, leaf area duration, sympodial branches and number of bolls leading to higher seed cotton yield of both cotton cultivars grown under conventional row spacing. While application of MC averts the plant growth without considerably improving the productivity. MLE being rich source of growth promoting hormone and nutrients showed its potential to a far greater extent under conventional row spacing in efficient utilization of available resources compared to $\mathrm{MC}$ and distilled water.
\end{abstract}

Keywords: moringa leaf extract, mepiquat chloride, Bt cotton, ultra narrow row.

\section{Eficiência do uso de recursos do algodão na geometria de plantio melhorada vs convencional com aplicação exógena de bioestimulante e retardante de crescimento sintético}

\begin{abstract}
Resumo
Reguladores de crescimento de plantas e melhor densidade de plantio são técnicas inovadoras no estabelecimento de culturas mais produtivas de algodão. Um estudo de campo foi planejado com o objetivo de avaliar o papel dos reguladores de crescimento na eficiência de uso de recursos de cultivares de algodão sob diferentes espaçamentos na Área de Pesquisa Agronômica, da Universidade Multil de Bahauddin Zakariya, e na Fazenda Agrícola da Usmania, Shujabad, durante o Kharif 2012. O estudo foi composto de cultivares de algodão CIM-573 e CIM-598, cultivados em espaçamento de linhas convencional $(75 \mathrm{~cm})$, médio $(50 \mathrm{~cm})$ e superestreito $(25 \mathrm{~cm})$ e de pulverização foliar de reguladores de crescimento, a saber, extrato de folhas de moringa (MLE) e cloreto de mepiquat (MC), isoladamente ou em combinação, e água destilada como controle. A aplicação de MLE isoladamente e em combinação (MLE + MC) mostrou efeito promotor na taxa de crescimento da cultura, taxa de assimilação líquida, índice de área foliar, duração de área foliar, ramos simpodiais e número de cápsulas levando à maior produção de algodão nas cultivares com espaçamento de linha convencional. Em contrapartida, a aplicação de MC evitou o crescimento da planta sem melhorar consideravelmente a produtividade. O MLE, por ser uma rica fonte de hormônio promotor de crescimento e nutrientes, mostrou seu potencial em uma extensão muito maior sob o espaçamento convencional entre as linhas no uso eficiente dos recursos disponíveis em comparação com o MC e a água destilada.
\end{abstract}

Palavras-chave: extrato de folhas de moringa, cloreto de mepiquat, algodão $\mathrm{Bt}$, linha superestreita. 


\section{Introduction}

The management of available resources i.e. land, water, seed, optimum growing season and labour to enhance their utilization is one of the key factors in crop management practice. The establishment of an acceptable plant population especially in cotton has their own importance for maximization of yields (Arif et al., 2012). The ultra-narrow row spaced cotton has long been seen as a probable substitute to conventional systems that enhanced the productivity under marginal and low production areas (Nawaz et al., 2015). However, higher cotton plant population had earlier canopy development, and self-shading hinders the solar radiation prevalence on lower leaves resulting in the reduction of photosynthesis and assimilate production, which resulting in loss of seed cotton yield and fiber quality (Brodrick et al., 2013).

Application of plant growth retardants is one of the approaches normally used in cotton production for modifying morphological and reproductive growth which helps in enhancing the cotton productivity by reducing the auto-shading (Gonias et al., 2012). Several studies hypothesize that mepiquat chloride (MC) inhibits the biosynthesis of gibberellic acid to reduce the cell elongation which results in shortened internodal elongation, decreased main stem nodes and declined leaf expansion in cotton (Rademacher, 2000). Use of MC improved the photosynthesis mechanism and canopy $\mathrm{CO}_{2}$ exchange rate, in relation with a greater specific leaf weight considering that additional amount of carbohydrates stored in the leaves (Zhao and Oosterhuis, 2000). Cotton plants produced thicker leaves having excessive chlorophyll that influence the photosynthetic potential and productivity (Fan et al., 2013).

In addition to growth retardants, some promoters also reported to improve the growth and productivity (Balakumbahan and Rajamani, 2010). Growth promoters stimulate the development of root system, leaf area, fortifying the photosynthetic process, develop resistance and hence enhance the productivity (Kamran et al., 2016). Among numerous natural sources, moringa (Moringa oleifera) leaf extract (MLE) has been showed its potential as an organic plant growth promoter (Yasmeen et al., 2013) being rich in ascorbates, amino acids, potassium, calcium, iron and zeatin like growth promoting substances is recognized as superlative plant growth promoter (Yasmeen et al., 2016). Its application encourages the optimum growth and development of plants and improves the production usually up to $20-35 \%$ (Arif et al., 2019). Therefore, the present study planned to evaluate efficiency of foliarly applied MLE individually or in combination with MC on cotton cultivars planted under conventional and improved planting geometry.

\section{Materials and Methods}

\subsection{Experimental and soil description}

Field study was planned to explore the role of growth regulators on growth and productivity of cotton cultivars under different row spacing at Agronomic
Research Area, Bahauddin Zakariya University Multan $\left(30.2639{ }^{\circ} \mathrm{N}, 71.5101{ }^{\circ} \mathrm{E} ; 123 \mathrm{~m}\right.$ asl) and Usmania Agricultural Farm, Shujabad (29.7686 ${ }^{\circ} \mathrm{N}, 71.3283{ }^{\circ} \mathrm{E}$; $152 \mathrm{~m}$ asl) during Kharif 2012. The trial was designed in completely randomized with factorial structure having 3 replications. The study was comprised of two cotton cultivars i.e., CIM-573 (Non Bt) and CIM-598 (Bt), grown under conventional $(75 \mathrm{~cm})$, medium $(50 \mathrm{~cm})$ and improved ultra-narrow row spacing $(25 \mathrm{~cm})$, and foliar spray of growth enhancer moringa leaf extract (MLE, 30 times diluted) and growth retardant mepiquat chloride ( $\mathrm{MC}, 42 \mathrm{~g}^{\mathrm{a} . \mathrm{i}} \mathrm{ha}^{-1}$ ), either alone or in combinations and distilled water as a control. MLE and MC treatments were foliarly applied between 10:00 and 11:30 am at beginning of bloom, 45 and 90 days after blooming by using a hand sprayer. The soil texture was silt loam, with $\mathrm{pH} 9.3$ and 7.90, EC 0.99 and $1.11 \mathrm{dS} \mathrm{m}^{-1}$, total nitrogen 0.021 and $0.0521 \%$, available phosphorus 3.00 and 7.05 ppm, exchangeable potassium 180 and $148 \mathrm{ppm}$ and organic matter 0.34 and $0.66 \%$ in Shujabad and Multan, respectively.

\subsection{Preparation of moringa leaf extract}

Fresh leaves and tender twigs of Moringa oleifera plants grown in botanical garden was harvested and washed several times with distilled water. This material was frozen $\left(-5^{\circ} \mathrm{C}\right)$ for 12 hours and pressed for extraction in a locally fabricated machine according to procedure described by Yasmeen et al. (2014). This extract was filtered twice by using Whatman No. 1 filter paper and then centrifuged at $8000 \mathrm{~g}$ for $15 \mathrm{~min}$ and diluted 30 times by using distilled water. Using different methodologies, moringa leaf extract (MLE) was analyzed for chemical composition. Eighteen chemical constituents were identified in the moringa leaf extract; they are total soluble protein $\left(1.40 \mathrm{mg} \mathrm{g}^{-1}\right)$, super oxide dismutase (191.86 IU $\mathrm{min}^{-1} \mathrm{mg}$ protein ${ }^{-1}$ ), peroxidase $\left(21.99 \mathrm{mmol} \mathrm{min}^{-1} \mathrm{mg}\right.$ protein $\left.{ }^{-1}\right)$, catalase (7.09 $\mathrm{mmol} \mathrm{min}^{-1} \mathrm{mg}$ protein $\left.{ }^{-1}\right)$, total phenolic contents $\left(8.19 \mathrm{mg} \mathrm{g}^{-1}\right)$, ascorbic acid $\left(0.36 \mathrm{~m} \mathrm{~mole}^{-1}\right)$, gibberellins $\left(0.74 \mathrm{mg} \mathrm{g}^{-1}\right)$, zeatin $\left(0.96 \mathrm{mg} \mathrm{g}^{-1}\right)$, nitrogen $(1.93 \%)$, phosphorus $(0.18 \%)$, Potassium $(2.19 \%)$, Calcium (2.43\%), Magnesium (0.012\%), Zinc (38.33 $\left.\mathrm{mg} \mathrm{kg}^{-1}\right)$, Copper (3.50 mg kg-1), iron (544 mg kg-1), manganese (49.67 $\mathrm{mg} \mathrm{kg}^{-1}$ ) and boron (21.33 $\left.\mathrm{mg} \mathrm{kg}^{-1}\right)$.

\subsection{Crop husbandry}

Fine seedbed was prepared with cultivator and $4.5 \mathrm{~m} \mathrm{x} 4.0 \mathrm{~m}$ beds were prepared with bed shaper. Delinted seeds of conventional cultivar CIM-573 and Bt cultivar CIM-598 were dibbled manually on $28^{\text {th }}$ March 2012. Plant to plant distance was kept $30 \mathrm{~cm}$ in each case. Plant population was approximately 129000,64500 and 43000 plants ha ${ }^{-1}$ in $25 \mathrm{~cm}, 50 \mathrm{~cm}$ and $75 \mathrm{~cm}$ in row to row spacing, respectively. First irrigation was applied followed by dibbling to get maximum germination percentage. Subsequent irrigations were applied depending upon crop requirements until last week of August. To get optimum plant population, gap filling and thinning was done on $12^{\text {th }}$ and $23^{\text {rd }}$ day of emergence, respectively. Recommended dose of nitrogen 
fertilizer i.e. 145 and $114 \mathrm{~kg} \mathrm{ha}^{-1}$ for Bt and conventional cotton cultivar, respectively, was used in 3 splits i.e. at the time of sowing, start of blooming and peak flowering stage. While recommended dose of phosphorus and potassium fertilizers i.e. 56 and $62 \mathrm{~kg} \mathrm{ha}^{-1}$ were applied at the time of sowing. All other agronomic practices were kept similar for each experimental unit.

\subsection{Data collection}

At the start of blooming, ten plants were selected randomly in each experimental unit and tagged to record the data on various quality parameters through adopting standard procedures. Growth parameters were examined five times during growing seasons at both locations. The absolute growth rate was calculated by using the equation (AGR $=\mathrm{W}_{2}-\mathrm{W}_{1} / \mathrm{t}_{2}-\mathrm{t}_{1}$ ) of Radford (1967) and articulated in g day $^{-1}$, where $\mathrm{W}_{1}$ is the dry weight of plant sampled at $t_{1}$ and $\mathrm{W}_{2}$ is the dry weight of plant sampled at $\mathrm{t}_{2}$. Crop growth rate $\left(\mathrm{g} \mathrm{m}^{-2} \mathrm{day}^{-1}\right)=\left(\mathrm{W}_{2}-\mathrm{W}_{1}\right) /\left(\mathrm{T}_{2}-\mathrm{T}_{1}\right)$, net assimilation rate $\left(\mathrm{g} \mathrm{m}^{-2}\right.$ day $\left.^{-1}\right)=\mathrm{TDM} / \mathrm{LAD}$ and leaf area duration $(\mathrm{LAD})=\left(\mathrm{LAI}_{1}+\mathrm{LAI}_{2}\right) \times\left(\mathrm{T}_{2}-\mathrm{T}_{1}\right) / 2$, were determined according to the procedure followed by Hunt (1978) where TDM= total dry matter accumulated between two harvests, $\mathrm{W}_{1}=$ oven-dry weight of first harvest, $\mathrm{W}_{2}=$ oven-dry weight of second harvest, and $\mathrm{T}_{2}-\mathrm{T}_{1}=$ time interval between two harvests. Leaf area index was calculated at various growth stages by adopting the equation (LAI= leaf area per plant/land area covered) recommended by Sestak et al. (1971). The crop was harvested when the cotton bolls were about $60 \%$ opened and data regarding agronomic and yield-related traits were recorded by following standard procedures.

\subsection{Statistical analysis}

Analysis of variance (ANOVA) of the collected data was carried out by using the statistical software M STAT. Difference among various treatment means were compared by DMR test at 5\% probability (Steel et al., 1997).

\section{Results}

In present study, foliar spray of growth regulators considerably influenced all the growth and yield attributes of cotton cultivars cultivated under different planting geometry. Foliar spray of MLE produced maximum AGR and CGR in CIM 598 cultivated under conventional row spacing of $75 \mathrm{~cm}$ and minimum was observed for CIM 573 cultivated under ultra narrow row spacing of $25 \mathrm{~cm}$ treated with foliar spray of $\mathrm{MC}$ at both locations (Figure 1 and 2). Net assimilation rate (NAR) followed an increasing trend in the primary stages of cotton growth and then reduced subsequently (Figure 3). Exogenous application of MLE produced significantly higher NAR from $\mathrm{Bt}$ cotton cultivated under conventional row spacing of $75 \mathrm{~cm}$ against the lower NAR for CIM 573 cultivated under ultra narrow row spacing of $25 \mathrm{~cm}$ treated with exogenous application of MC in Multan. However, combined application of MLE + MC produced significantly higher NAR from CIM 573 cultivated under conventional row spacing of $75 \mathrm{~cm}$ in Shujabad. While exogenous application of distilled water produced lower NAR from conventional cotton cultivar CIM 573

Exogenous application of MLE and its combination with MC produced maximum LAI for CIM 598 cultivated under row spacing of $75 \mathrm{~cm}$ in Multan and Shujabad, respectively (Figure 4). Minimum LAI was noted for CIM

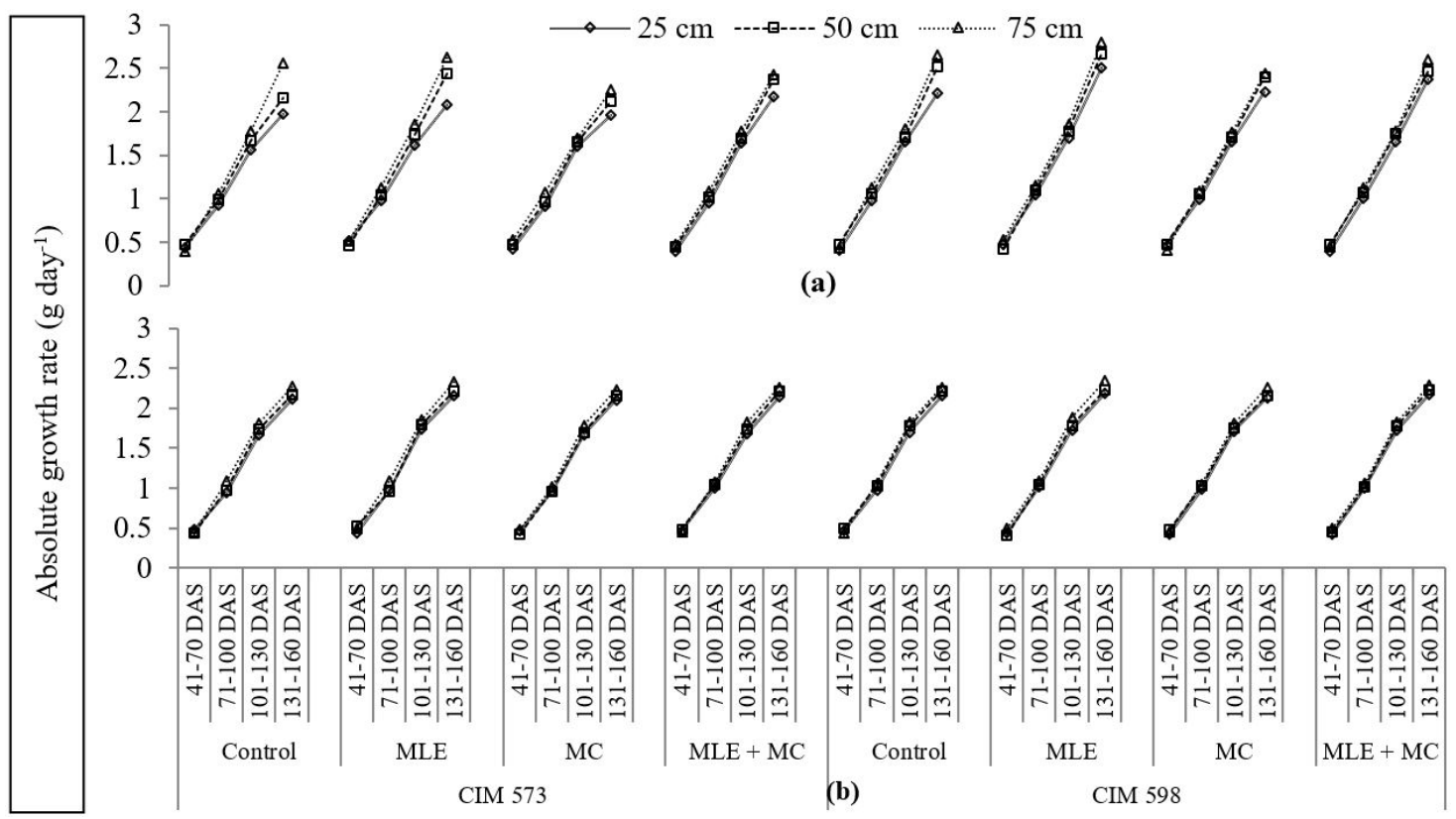

Figure 1. Influence of growth regulators on absolute growth rate of cotton cultivars grown under different planting geometry in Multan (a) and Shujabad (b). 
573 cultivated under ultra narrow row spacing of $25 \mathrm{~cm}$ in control plots. Exogenous application of MLE produced significantly higher leaf area duration (LAD) from CIM 598 cultivated under row spacing of $75 \mathrm{~cm}$ at both sites (Figure 5). Lower LAD was noted for CIM 573 cultivated under row spacing of $25 \mathrm{~cm}$ with foliar spray of distilled water and MC in Multan and Shujabad, respectively.

Foliar spray of MLE on CIM 573 cultivated under ultra narrow row spacing of $25 \mathrm{~cm}$ produced significantly taller plants (Figure 6). While exogenous application

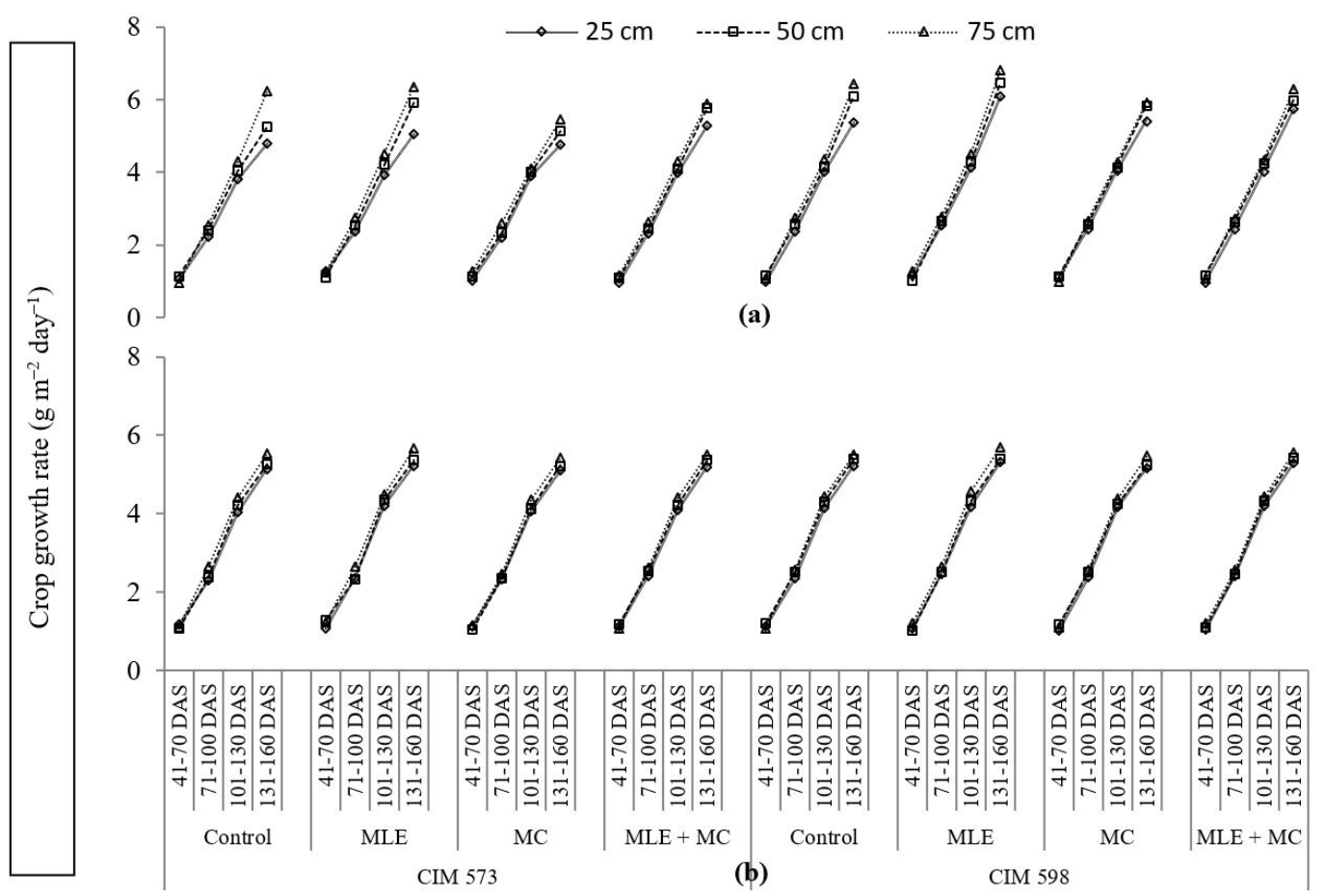

Figure 2. Influence of growth regulators on crop growth rate of cotton cultivars grown under different planting geometry in Multan (a) and Shujabad (b).

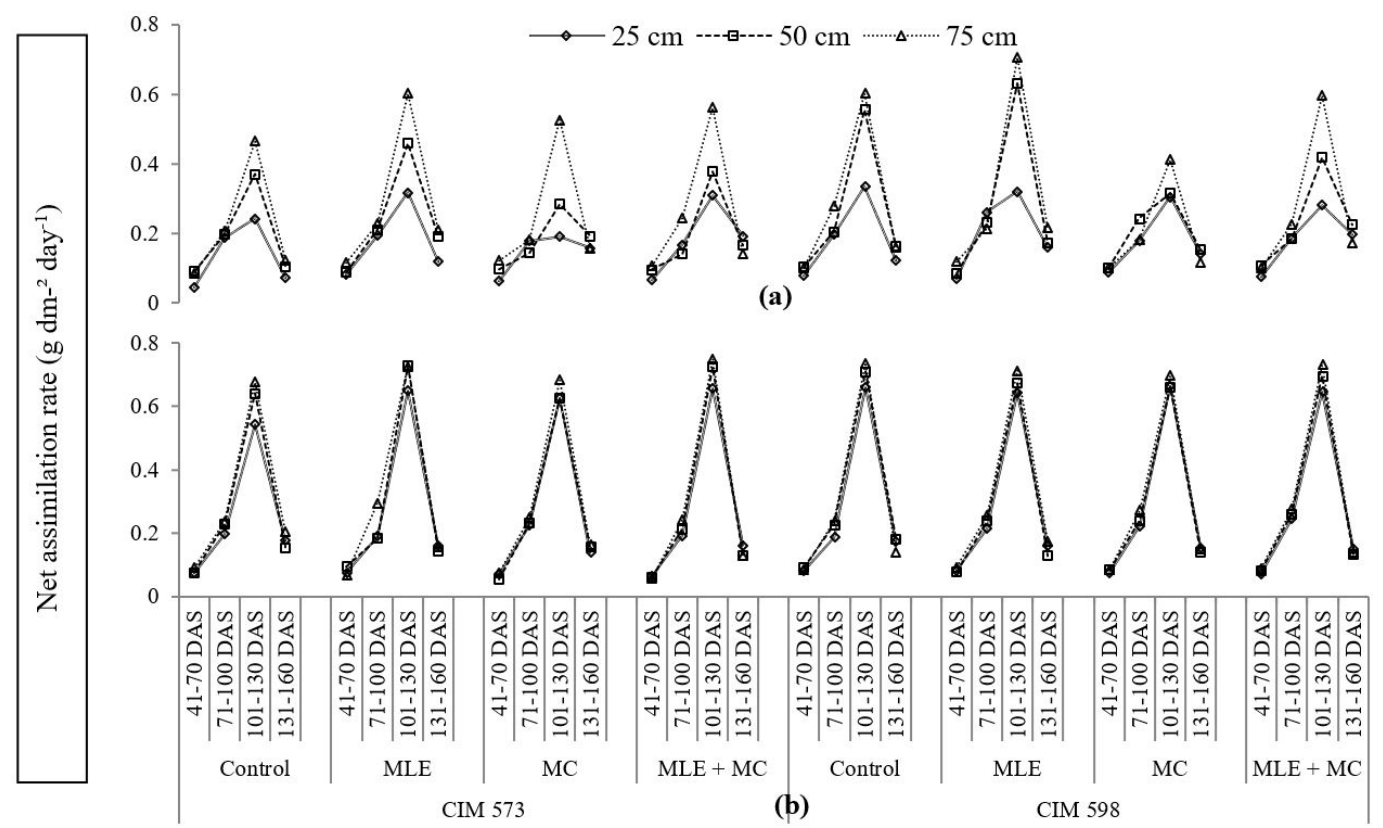

Figure 3. Influence of growth regulators on net assimilation rate of cotton cultivars grown under different planting geometry in Multan (a) and Shujabad (b). 
of MC produced minimum plant height in CIM 598 cultivated under row spacing of $75 \mathrm{~cm}$ at both sites. Similarly, foliar spray of MLE produced maximum sympodial branches in CIM 598 grown at row spacing of $75 \mathrm{~cm}$ (Table 1). Lowest sympodial branches were documented for CIM 573 planted under ultra-narrow row spacing for control and MC treated plots in Multan and Shujabad, respectively.

Foliar spray of MLE alone and in combination $(\mathrm{MLE}+\mathrm{MC})$ on Bt cotton planted under row spacing of $75 \mathrm{~cm}$ harvested more bolls per plant in Multan and Shujabad, respectively (Table 1). While minimum
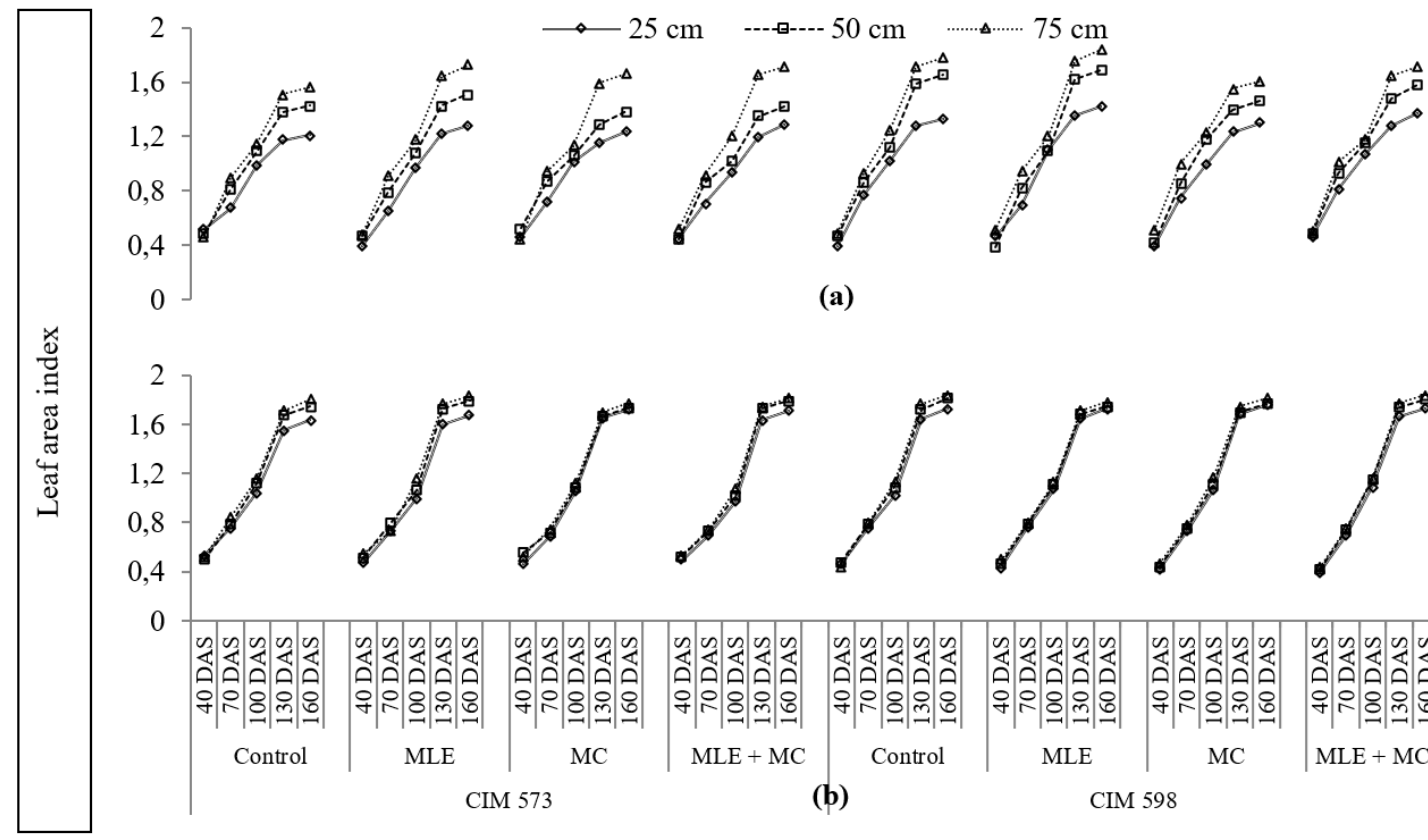

(a)
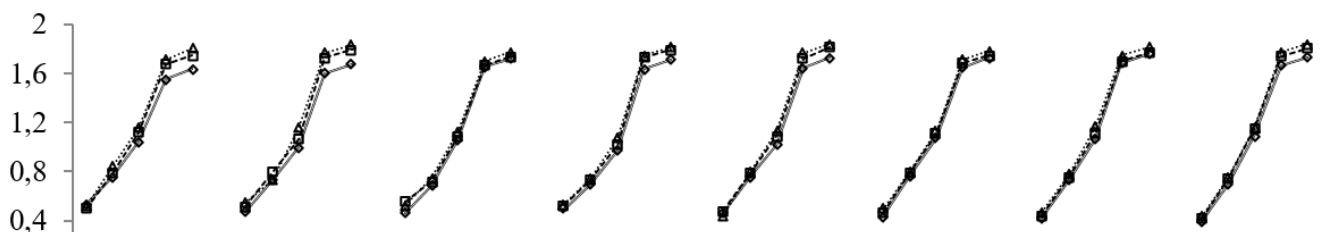

0

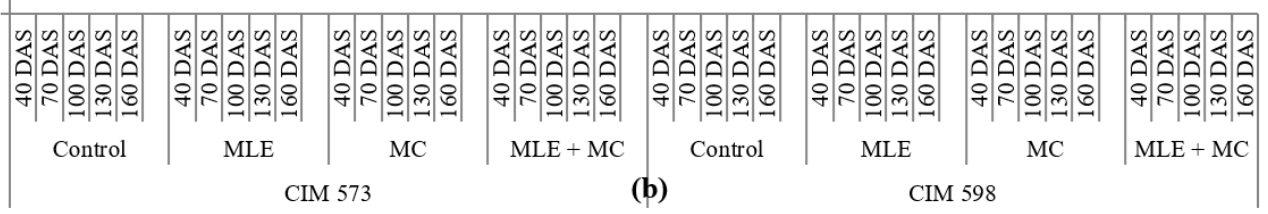

Figure 4. Influence of growth regulators on leaf area index of cotton cultivars grown under different planting geometry in Multan (a) and Shujabad (b).
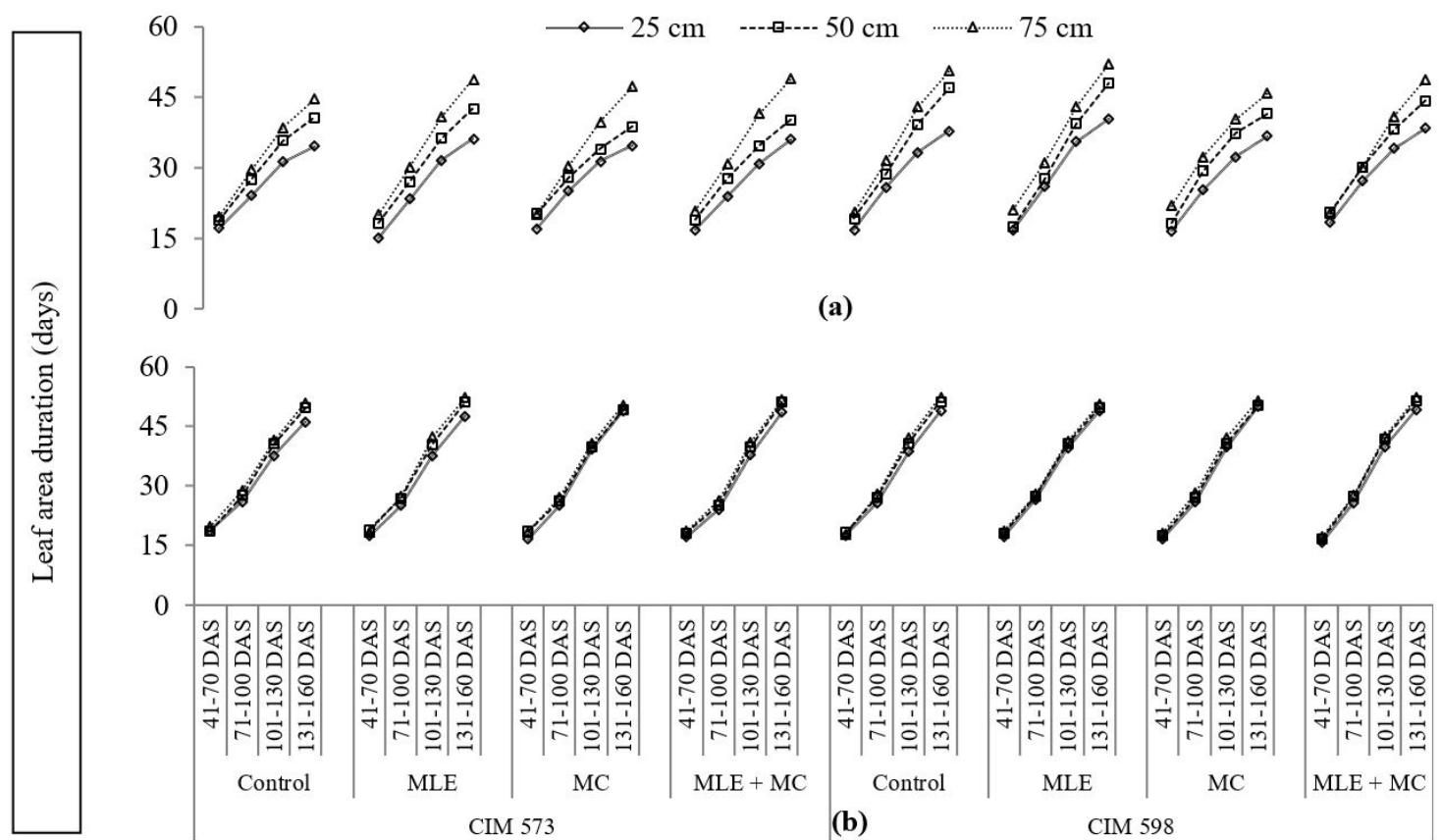

(a)
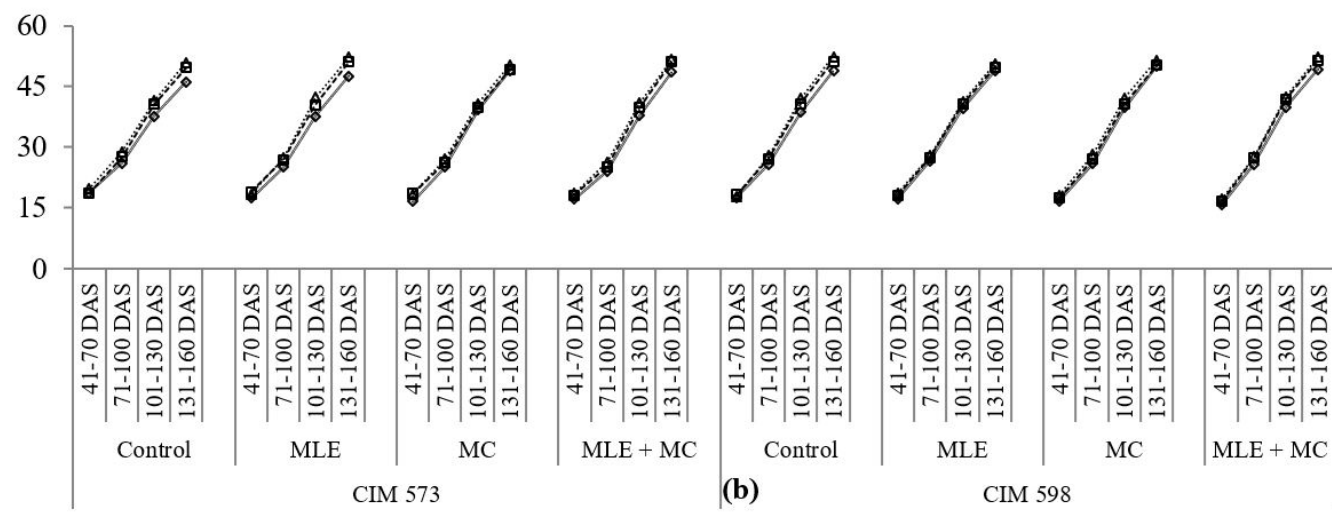

Figure 5. Influence of growth regulators on leaf area duration of cotton cultivars grown under different planting geometry in Multan (a) and Shujabad (b). 


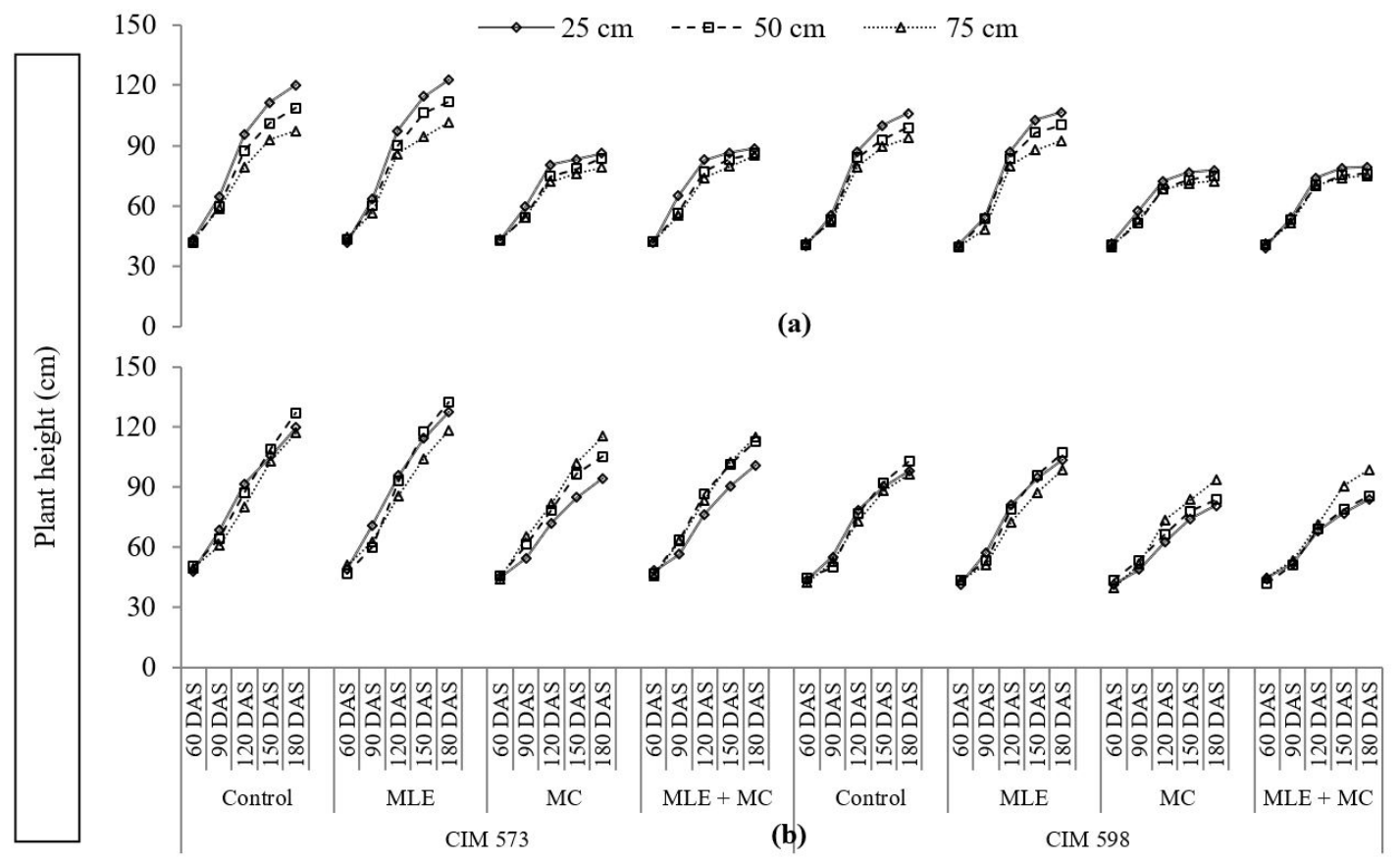

Figure 6. Influence of growth regulators on plant height $(\mathrm{cm})$ of cotton cultivars grown under different planting geometry in Multan (a) and Shujabad (b).

Table 1. Influence of growth regulators on yield contributing attributes of cotton cultivars cultivated under different planting geometry.

\begin{tabular}{|c|c|c|c|c|c|c|c|c|}
\hline \multicolumn{3}{|c|}{ Treatments } & \multicolumn{2}{|c|}{$\begin{array}{c}\text { Sympodial branches } \\
\text { per plant }\end{array}$} & \multicolumn{2}{|c|}{ No. of bolls per plant } & \multicolumn{2}{|c|}{ Mean boll weight (g) } \\
\hline Cultivar & Foliar spray & $\begin{array}{c}\text { Row spacing } \\
(\mathrm{cm})\end{array}$ & Multan & Shujabad & Multan & Shujabad & Multan & Shujabad \\
\hline \multirow[t]{12}{*}{ CIM 573} & Distilled & 25 & $7.14 \mathrm{j}$ & $8.04 \mathrm{f}$ & $8.98 \mathrm{~g}$ & $9.78 \mathrm{i}$ & $2.64 \mathrm{f}$ & $2.77 \mathrm{fg}$ \\
\hline & water & 50 & 12. fi & $14.11 \mathrm{e}$ & $15.66 \mathrm{ef}$ & $16.47 \mathrm{gh}$ & $2.76 \mathrm{ef}$ & $2.82 \mathrm{eg}$ \\
\hline & & 75 & $18.91 \mathrm{ad}$ & $20.14 b$ & $25.57 \mathrm{c}$ & $27.60 \mathrm{de}$ & 3.07 af & $2.97 \mathrm{bf}$ \\
\hline & MLE & 25 & $8.75 \mathrm{ij}$ & $9.07 \mathrm{f}$ & $10.84 \mathrm{~g}$ & $12.15 \mathrm{hi}$ & $2.67 \mathrm{f}$ & $2.78 \mathrm{fg}$ \\
\hline & & 50 & $15.21 \mathrm{df}$ & $15.90 \mathrm{de}$ & $19.97 \mathrm{~d}$ & $22.04 \mathrm{f}$ & $2.88 \mathrm{bf}$ & $2.95 \mathrm{bg}$ \\
\hline & & 75 & $21.04 \mathrm{ab}$ & $21.15 \mathrm{~b}$ & $29.51 b$ & $33.78 \mathrm{c}$ & $3.17 \mathrm{ae}$ & $3.08 \mathrm{ac}$ \\
\hline & MC & 25 & $7.28 \mathrm{j}$ & $7.64 \mathrm{f}$ & $11.19 \mathrm{~g}$ & $11.83 \mathrm{hi}$ & $2.68 \mathrm{f}$ & $2.80 \mathrm{eg}$ \\
\hline & & 50 & $12.57 \mathrm{fi}$ & $14.10 \mathrm{e}$ & $18.22 \mathrm{de}$ & $19.95 \mathrm{fg}$ & 2.98af & $2.86 \mathrm{dg}$ \\
\hline & & 75 & $18.63 \mathrm{ad}$ & $19.09 \mathrm{bc}$ & $27.14 \mathrm{bc}$ & $28.58 \mathrm{~d}$ & $3.24 \mathrm{ac}$ & $3.11 \mathrm{ac}$ \\
\hline & MLE + MC & 25 & $8.59 \mathrm{ij}$ & $7.86 \mathrm{f}$ & $11.33 \mathrm{~g}$ & 12.34hi & $2.87 \mathrm{bf}$ & $2.78 \mathrm{fg}$ \\
\hline & & 50 & $13.91 \mathrm{eh}$ & $14.61 \mathrm{e}$ & $19.02 \mathrm{de}$ & $21.00 \mathrm{fg}$ & $3.15 \mathrm{ae}$ & 3.0 be \\
\hline & & 75 & $19.12 \mathrm{ad}$ & $20.04 \mathrm{~b}$ & $28.77 \mathrm{bc}$ & $31.12 \mathrm{~cd}$ & $3.29 \mathrm{ab}$ & $3.21 \mathrm{a}$ \\
\hline \multirow[t]{12}{*}{ CIM 598} & Distilled & 25 & $8.94 \mathrm{ij}$ & $8.63 \mathrm{f}$ & $11.70 \mathrm{~g}$ & 11.99hi & 2.74 ef & $2.76 \mathrm{~g}$ \\
\hline & water & 50 & $15.89 \mathrm{cf}$ & $15.82 \mathrm{de}$ & $19.77 \mathrm{~d}$ & $20.88 \mathrm{fg}$ & $2.82 \mathrm{cf}$ & $2.88 \mathrm{dg}$ \\
\hline & & 75 & $20.13 \mathrm{ac}$ & $23.56 \mathrm{a}$ & $33.37 \mathrm{a}$ & $34.97 \mathrm{bc}$ & 3.10 af & $3.05 \mathrm{ad}$ \\
\hline & MLE & 25 & $10.34 \mathrm{gj}$ & $8.77 f$ & $12.93 \mathrm{fg}$ & $12.73 \mathrm{hi}$ & $2.77 \mathrm{df}$ & $2.83 \mathrm{eg}$ \\
\hline & & 50 & 17.01be & $17.14 \mathrm{~cd}$ & $20.93 \mathrm{~d}$ & $21.87 \mathrm{f}$ & $2.94 \mathrm{bf}$ & $2.93 \mathrm{cg}$ \\
\hline & & 75 & $23.02 \mathrm{a}$ & $24.36 \mathrm{a}$ & $36.44 \mathrm{a}$ & $41.66 \mathrm{a}$ & 3.19 ae & $3.15 \mathrm{ab}$ \\
\hline & MC & 25 & $8.98 \mathrm{ij}$ & $8.25 \mathrm{f}$ & $13.02 \mathrm{fg}$ & $14.33 \mathrm{hi}$ & $2.84 \mathrm{bf}$ & $2.82 \mathrm{eg}$ \\
\hline & & 50 & $14.13 \mathrm{eg}$ & $15.49 \mathrm{de}$ & $21.13 \mathrm{~d}$ & $23.47 \mathrm{ef}$ & $3.04 \mathrm{af}$ & $2.86 \mathrm{dg}$ \\
\hline & & 75 & $20.21 \mathrm{ac}$ & $20.25 \mathrm{~b}$ & $33.58 \mathrm{a}$ & $34.25 \mathrm{c}$ & $3.23 \mathrm{ad}$ & $3.11 \mathrm{ac}$ \\
\hline & MLE + MC & 25 & $9.81 \mathrm{hj}$ & $8.79 \mathrm{f}$ & $13.06 \mathrm{fg}$ & 14.46hi & $2.85 \mathrm{bf}$ & $2.83 \mathrm{eg}$ \\
\hline & & 50 & $16.66 \mathrm{bf}$ & $16.42 \mathrm{de}$ & $21.10 \mathrm{~d}$ & $23.40 \mathrm{ef}$ & $3.09 \mathrm{af}$ & $2.96 \mathrm{bg}$ \\
\hline & & 75 & $20.41 \mathrm{ab}$ & $21.45 \mathrm{~b}$ & $33.74 \mathrm{a}$ & $39.09 \mathrm{ab}$ & $3.40 \mathrm{a}$ & $3.23 \mathrm{a}$ \\
\hline LSD $0.05 p$ & & & 3.80 & 2.09 & 3.55 & 4.73 & 0.39 & 0.18 \\
\hline
\end{tabular}


Table 2. Influence of growth regulators on seed index, seed cotton yield and ginning percentage of cotton cultivars cultivated under different planting geometry.

\begin{tabular}{|c|c|c|c|c|c|c|c|c|}
\hline \multicolumn{3}{|c|}{ Treatments } & \multicolumn{2}{|c|}{ Seed index (g) } & \multicolumn{2}{|c|}{$\begin{array}{c}\text { Seed cotton yield } \\
\left(\mathrm{kg} \mathrm{ha}^{-1}\right)\end{array}$} & \multicolumn{2}{|c|}{$\begin{array}{c}\text { Ginning percentage } \\
(\%)\end{array}$} \\
\hline Cultivar & Foliar spray & $\begin{array}{c}\text { Row spacing } \\
\text { (cm) }\end{array}$ & Multan & Shujabad & Multan & Shujabad & Multan & Shujabad \\
\hline \multirow[t]{12}{*}{ CIM 573} & \multirow{3}{*}{$\begin{array}{c}\text { Distilled } \\
\text { water }\end{array}$} & 25 & $6.96 \mathrm{e}$ & 7.07 & $1318 \mathrm{gh}$ & $1573 \mathrm{fg}$ & $38.64 \mathrm{~b}$ & $36.50 \mathrm{bc}$ \\
\hline & & 50 & $7.01 \mathrm{ce}$ & 7.16 & $1239 \mathrm{~h}$ & $1426 \mathrm{~g}$ & $40.47 \mathrm{ab}$ & $35.95 \mathrm{c}$ \\
\hline & & 75 & $7.31 \mathrm{ae}$ & 7.44 & $1664 \mathrm{dh}$ & $1745 \mathrm{eg}$ & $40.65 \mathrm{ab}$ & $39.87 \mathrm{ac}$ \\
\hline & \multirow[t]{3}{*}{ MLE } & 25 & $6.98 \mathrm{de}$ & 7.25 & $1624 \mathrm{fh}$ & $1982 \mathrm{bf}$ & $39.79 \mathrm{ab}$ & $37.75 \mathrm{ac}$ \\
\hline & & 50 & $7.15 \mathrm{ae}$ & 7.36 & $1729 \mathrm{dh}$ & $1989 \mathrm{bf}$ & $39.87 \mathrm{ab}$ & $40.13 \mathrm{ac}$ \\
\hline & & 75 & $7.53 \mathrm{ae}$ & 7.5 & $1969 \mathrm{cf}$ & 2154 be & 40.09ab & $40.59 \mathrm{ab}$ \\
\hline & \multirow[t]{3}{*}{ MC } & 25 & 7.13ae & 7.28 & $1745 \mathrm{dh}$ & $2026 \mathrm{bf}$ & $39.65 \mathrm{ab}$ & $36.67 \mathrm{bc}$ \\
\hline & & 50 & 7.19ae & 7.47 & $1656 \mathrm{eh}$ & $1752 \mathrm{eg}$ & $40.36 \mathrm{ab}$ & $37.62 \mathrm{ac}$ \\
\hline & & 75 & $7.59 \mathrm{ad}$ & 7.53 & $1925 \mathrm{cf}$ & $1790 \mathrm{dg}$ & $40.61 \mathrm{ab}$ & $39.44 \mathrm{ac}$ \\
\hline & \multirow[t]{3}{*}{ MLE + MC } & 25 & 7.09ae & 7.22 & $1867 \mathrm{cg}$ & $1989 \mathrm{bf}$ & $39.47 \mathrm{ab}$ & $37.76 \mathrm{ac}$ \\
\hline & & 50 & $7.27 \mathrm{ae}$ & 7.57 & $1815 \mathrm{ch}$ & 1936 bf & $40.08 \mathrm{ab}$ & $39.63 \mathrm{ac}$ \\
\hline & & 75 & $7.71 \mathrm{a}$ & 7.59 & $2030 \mathrm{bf}$ & 2123 be & $39.72 \mathrm{ab}$ & $41.15 \mathrm{a}$ \\
\hline \multirow[t]{12}{*}{ CIM 598} & \multirow{3}{*}{$\begin{array}{l}\text { Distilled } \\
\text { water }\end{array}$} & 25 & $6.94 \mathrm{e}$ & 7.11 & $1810 \mathrm{ch}$ & 1942 bf & $38.73 \mathrm{~b}$ & 39.19ac \\
\hline & & 50 & $7.02 \mathrm{ce}$ & 7.19 & $1641 \mathrm{eh}$ & $1841 \mathrm{cg}$ & $39.23 \mathrm{ab}$ & $40.31 \mathrm{ab}$ \\
\hline & & 75 & $7.56 \mathrm{ae}$ & 7.24 & $2274 \mathrm{ad}$ & $2332 b$ & $39.26 \mathrm{ab}$ & $40.61 \mathrm{ab}$ \\
\hline & \multirow[t]{3}{*}{ MLE } & 25 & $6.96 \mathrm{e}$ & 7.14 & $1972 \mathrm{cf}$ & 2147 be & $39.69 \mathrm{ab}$ & $38.47 \mathrm{ac}$ \\
\hline & & 50 & $7.3 \mathrm{ae}$ & 7.18 & $1864 \mathrm{cg}$ & $2000 \mathrm{bf}$ & $40.07 \mathrm{ab}$ & $40.41 \mathrm{ab}$ \\
\hline & & 75 & $7.54 \mathrm{ae}$ & 7.24 & $2600 \mathrm{ab}$ & $2885 \mathrm{a}$ & $39.67 \mathrm{ab}$ & $41.31 \mathrm{a}$ \\
\hline & \multirow[t]{3}{*}{ MC } & 25 & 7.04 be & 7.15 & 2155 af & $2297 \mathrm{bc}$ & $40.21 \mathrm{ab}$ & $39.04 \mathrm{ac}$ \\
\hline & & 50 & $7.64 \mathrm{ac}$ & 7.23 & $2000 \mathrm{cf}$ & 2013 bf & $41.10 \mathrm{ab}$ & $40.63 \mathrm{ab}$ \\
\hline & & 75 & $7.66 \mathrm{ab}$ & 7.28 & $2411 \mathrm{ac}$ & $2255 \mathrm{bd}$ & $41.22 \mathrm{ab}$ & $40.02 \mathrm{ac}$ \\
\hline & \multirow[t]{3}{*}{ MLE + MC } & 25 & 7.05 be & 7.17 & 2241ae & $2359 \mathrm{~b}$ & $40.14 a b$ & $39.22 \mathrm{ac}$ \\
\hline & & 50 & $7.70 \mathrm{a}$ & 7.25 & $1937 \mathrm{cf}$ & 2148 be & $41.22 \mathrm{ab}$ & $39.72 \mathrm{ac}$ \\
\hline & & 75 & $7.69 \mathrm{a}$ & 7.29 & $2652 \mathrm{a}$ & $2754 a$ & $41.92 \mathrm{a}$ & $40.14 \mathrm{ac}$ \\
\hline \multicolumn{3}{|c|}{ LSD $0.05 p=$} & 0.52 & N.S & 507.22 & 388.17 & 2.58 & 3.47 \\
\hline
\end{tabular}

number of bolls was harvested from CIM 573 in control plots. Exogenous application of MLE + MC produced considerably higher mean boll weight for CIM 598 cultivated under row spacing of $75 \mathrm{~cm}$ (Table 1). While foliar spray of distilled water produced lower mean boll weight noted for the CIM 573 and CIM 598 cotton cultivars planted under row spacing of $25 \mathrm{~cm}$ in Multan and Shujabad, respectively. Combined application (MLE + MC) produced significantly higher seed index for CIM 573 cotton cultivar planted under conventional row spacing in Multan (Table 2). Conversely, lower seed index was observed from CIM 598 planted under row spacing of $25 \mathrm{~cm}$ in control plots. Combined application $(\mathrm{MLE}+\mathrm{MC})$ also produced maximum seed cotton yield from CIM-598 planted under row spacing of $75 \mathrm{~cm}$ at both sites (Table 2). Whereas minimum seed cotton yield was recorded under medium row spacing of $50 \mathrm{~cm}$ from CIM 573 in control plots. Higher ginning percentage was recorded from CIM 598 planted at row spacing of $75 \mathrm{~cm}$ with foliar spray of combined (MLE + MC) against the lowest observed from control plots in CIM 573 planted at $50 \mathrm{~cm}$ and $25 \mathrm{~cm}$ row spacing (Table 2).

\section{Discussion}

Exogenous application of plant growth regulators affected the physiological processes of cotton cultivars planted under different planting geometry improved the growth and productivity. Foliar spray of MLE improved the LAI and LAD, which are responsible for higher productivity by providing more photosynthates for longer period (Yasmeen et al., 2013, 2016). Higher AGR, CGR, NAR and plant height recorded with the exogenous application of MLE, which may assist for improved biomass production and its translocation into various plant parts depends upon the photosynthetic capability of a plant (Manjunatha et al., 2010). This acceleration of growth attributes might be due to the enriched content of moringa leaf extract of nutrients and growth promoting hormone vital for the development of the protoplasm, cell multiplication and extension (Moyo et al., 2011). The ultra-narrow row spacing produced maximum plant height due to the availability of horizontal space for distinct plant. Similarly, higher plants competition for moisture, light and nutrients repressed the node formation and produced taller plants (Siebert and Stewart, 2006). MC being anti-gibberellin and its foliar 
spray enhanced the LAI at initial stage then decreased (Almeida and Rosolem, 2012), hence its use reduced the cell elongation, which results in condensed leaves (Souza and Rosolem, 2007). The obvious enhancements in growth parameters under conventional row spacing was observed due to the additional availability of sunlight that might help in synthesis and partitioning of photosynthates to distinct plant under wider row spacing, which eventually translocated the photo-assimilates from source to sink and triggered partitioning in biomass that leads substantial increase in growth parameters (Bhalerao et al., 2010).

More sympodial branches with foliar spray of MLE might be the effect of the higher photo-assimilates and growth promoting hormones in the plant. Whereas, reduced sympodial branches were recorded with the use of MC, which reduces the vegetative growth and hence improved the reproductive growth (Yasmeen et al., 2016). Improved sympodial branches under conventional row spacing might be due to less competition among plants for existing space that allowed the plants to accumulate more nutrients and water (Nadeem et al., 2010).

Combined application (MLE + MC) significantly improved the yield contributing attributes in $\mathrm{Bt}$ cotton cultivar CIM-598 under conventional row spacing of $75 \mathrm{~cm}$. MLE is being source of nutrients and growth enhancing hormone, enhanced the photosynthesis which improved the blooming and boll development (Yasmeen et al., 2018). Similarly, MC is used to regulate the reproductive growth and sustaining internal hormonal balance, effective sink source relationship, which improved yield contributing parameters depending on the enhanced photosynthetic activity (Zhao and Oosterhuis, 2000; Gwathmey and Clement, 2010). Final seed cotton yield indicated the cumulative influence of numerous yield contributing attributes. Combined application (MLE + MC) produced maximum seed cotton yield in CIM 598 planted under row spacing of $75 \mathrm{~cm}$. It is because MLE is rich in natural phytohormones along with other nutrients, which improved its productivity (Iqbal, 2014). Such enhancements in yield are associated with more number of bolls, higher leaf area, adjustment in source-sink relationship and deferred senescence (Yasmeen et al., 2013). Similarly, application of MC considerably improved the yield might be due to the fact that it controls the new growth with controlling the vegetative growth and accordingly improves reproductive growth by permitting the plants to translocate photosynthates towards the reproductive organs (Yasmeen et al., 2016). Consequently, MC treated plants have bolls with more photo-assimilate provided sink for carbohydrates and further metabolites (Kumar et al., 2004). Higher seed cotton yield with wider row spacing of $75 \mathrm{~cm}$ was the direct effect of higher number of bolls, mean boll weight and seed index can be credited to higher accessibility of nutrients, solar radiation and moisture which enhanced the photosynthetic efficiency with accumulation of metabolites with direct effect on boll weight (Kumar et al., 2004). Similarly, higher seed cotton yield and ginning percentage was documented for cultivar CIM-598 which might be due to their pre-eminence in genetic potential which produced more branches and bolls per plant (Aziz et al., 2011).

\section{Conclusion}

The application of MLE alone and in combination (MLE + MC) showed the promoting effect on crop growth rate, net assimilation rate, leaf area index, leaf area duration, sympodial branches and number of bolls leading to higher seed cotton yield of both cotton cultivars grown under conventional row spacing. MLE being rich source of growth promoting hormone and nutrients showed its potential to a far greater extent under conventional row spacing in efficient utilization of available resources compared to $\mathrm{MC}$ and distilled water.

\section{References}

Almeida, A.Q. and Rosolem, C.A., 2012. Cotton root and shoot growth as affected by application of mepiquat chloride to cotton seeds. Acta Scientiarum Agronomy, vol. 34, no. 1, pp. 61-65. http://dx.doi.org/10.4025/actasciagron.v34i1.12369.

Arif, M., Kareem, S.H.S., Ahmad, N.S., Hussain, N., Yasmeen, A., Anwar, A., Naz, S., Iqbal, J., Shah, G.A. and Ansar, M., 2019. Exogenously applied bio-stimulant and synthetic fertilizers to improve the growth, yield and fiber quality of cotton. Sustainability, vol. 11, no. 7, pp. 1-14. http://dx.doi.org/10.3390/su11072171.

Aziz, A., Akhtar, N., Afzal, M., Ashraf, M., Tanveer, A., Ahmad, R., Safdar, M.E. and Ahmad, S., 2011. Comparative performance of Bt cotton with some elite conventional cotton cultivars under arid to semi-arid conditions. African Journal of Agricultural Research, vol. 5, pp. 1600-1606.

Arif, M., Shehzad, M.A. and Mushtaq, S., 2012. Inter and intra row spacing effects on growth, seed yield and oil contents of white mustard (Sinapis alba L.) under rainfed conditions. Pakistan Journal of Agricultural Sciences, vol. 49, pp. 21-25.

Balakumbahan, R. and Rajamani, K., 2010. Effect of biostimulant on growth and yield of senna (cassia angustifuliavar KKM.1). Journal of Horticultural Science \& Ornamental Plants, vol. 2, pp. 16-18.

Bhalerao, P.D., Patil, B.R., Ghatol, P.U. and Gawande, P.P., 2010. Effect of spacing and fertilizer levels on seed cotton yield under rainfed condition. Indian Journal of Agricultural Research, vol. 44, pp. 74-77.

Brodrick, R., Bange, M.P., Milroy, S.P. and Hammer, G.L., 2013. Physiological determinants of high yielding ultra-narrow row cotton: canopy development and radiation use efficiency. Field Crops Research, vol. 148, pp. 86-94. http://dx.doi.org/10.1016/j. fcr.2012.05.008.

Fan, X.X., Xu, Z.G., Liu, X.Y., Tang, C.M., Wang, L.W. and Han, X.L., 2013. Effects of light intensity on the growth and leaf development of young tomato plants grown under a combination of red and blue light. Scientia Horticulturae, vol. 153, pp. 50-55. http://dx.doi.org/10.1016/j.scienta.2013.01.017.

Gonias, E.D., Oosterhuis, D.M. and Bibi, A.C., 2012. Cotton radiation use efficiency response to plant growth regulators. Journal of Agricultural Sciences, vol. 150, pp. 595-602.

Gwathmey, C.O. and Clement, J.D., 2010. Alteration of cotton source-sink relations with plant population density and mepiquat 
chloride. Field Crops Research, vol. 116, no. 1-2, pp. 101-107. http://dx.doi.org/10.1016/j.fcr.2009.11.019.

Hunt, R., 1978. The Institute of Biology's studies in biology $n^{\circ} 96$ : Plant growth analysis. London, UK: Edward Arnold Ltd., pp. 8-38.

Iqbal, M.A., 2014. Managing sunflower (Helianthus annuus L.) nutrition with foliar application of Moringa (Moringa oleifera Lam.) Leaf Extract. American-Eurasian Journal of Agricultural \& Environmental Sciences, vol. 14, pp. 1339-1345.

Kamran, M., Cheema, Z.A., Farooq, M. and Hassan, A.U., 2016. Influence of foliage applied allelopathic water extracts on the grain yield, quality and economic returns of hybrid maize. International Journal of Agriculture and Biology, vol. 18, no. 03, pp. 577-583. http://dx.doi.org/10.17957/IJAB/15.0128.

Kumar, K.A.K., Patil, B.C. and Chetti, M.B., 2004. Effect of plant growth regulators on biophysical, biochemical parameters and yield of hybrid cotton. Karnataka Journal of Agricultural Sciences, vol. 16, pp. 591-594.

Manjunatha, M.J., Halepyati, A.S., Koppalkar, B.G. and Pujari, B.T., 2010. Influence of different plant densities on the growth, yield and economics of Bt cotton (Gossypium hirsutum L.) genotypes under dryland condition. Karnataka Journal of Agricultural Sciences, vol. 23, pp. 580-583.

Moyo, B., Masika, P.J., Hugo, A. and Muchenje, V., 2011. Nutritional characterization of Moringa (Moringa oleifera Lam) leaves. African Journal of Biotechnology, vol. 10, no. 60, pp. 12925-12933. http://dx.doi.org/10.5897/AJB10.1599.

Nadeem, M.A., Ali, A., Tahir, M., Naeem, M., Chadhar, A.R. and Ahmad, S., 2010. Effect of nitrogen levels and plant spacing on growth and yield of cotton. Pakistan Journal of Life and Social Sciences, vol. 8, pp. 121-124.

Nawaz, H., Hussain, N., Rehmani, M.I.A., Yasmeen, A. and Arif, M., 2015. Comparative performance of cotton cultivars under conventional and ultra-narrow row (UNR) spacing. Pure and Applied Biology, vol. 5, pp. 15-25.

Rademacher, W., 2000. Growth retardants: Effects on gibberellin biosynthesis and other metabolic pathways. Annual Review of Plant Physiology and Plant Molecular Biology, vol. 51, no. 1, pp. 501-531. http://dx.doi.org/10.1146/annurev.arplant.51.1.501. PMid:15012200.

Radford, P.T., 1967. Growth analysis formulae, their use and abuse. Crop Science, vol. 8, no. 3, pp. 171-175. http://dx.doi. org/10.2135/cropsci1967.0011183X000700030001x.
Sestak, Z., Crelsky, J. and Jarvis, F.G. 1971. Plant photosynthetic production, animal of methods. The Hague: Dr. W. Junk, N. V., Publication, pp. 343-381.

Siebert, J.D. and Stewart, A.M., 2006. Influence of plant density on cotton response to mepiquat chloride application. Agronomy Journal, vol. 98, no. 6, pp. 1634-1639. http://dx.doi.org/10.2134/ agronj2006.0083.

Souza, F.S. and Rosolem, C.A., 2007. Rainfall intensity and mepiquat chloride persistence in cotton. Scientia Agrícola, vol. 64 , no. 2 , pp. 125-130. http://dx.doi.org/10.1590/S010390162007000200004 .

Steel, R.G.D., Torrie, J.H. and Deekey, D.A., 1997. Principles and procedures of Statistics: A biometrical approach. 3rd ed. McGraw Hill Book. Int. Co.: New York. pp. 400-428.

Yasmeen, A., Arif, M., Hussain, N., Naz, S. and Anwar, A., 2018. Economic analyses of sole and combined foliar application of moringa leaf extract (MLE) and $\mathrm{k}$ in growth and yield improvement of cotton. International Journal of Agriculture and Biology, vol. 20 , pp. $857-863$.

Yasmeen, A., Arif, M., Hussain, N., Malik, W. and Qadir, I., 2016. Morphological, growth and yield response of cotton to exogenous application of natural growth promoter and synthetic growth retardant. International Journal of Agriculture and Biology, vol. 18, no. 06, pp. 1109-1121. http://dx.doi.org/10.17957/IJAB/15.0213.

Yasmeen, A., Basra, S.M.A., Farooq, M., Rehman, H.U., Hussain, N. and Athar, H.U.R., 2013. Exogenous application of moringa leaf extract modulates the antioxidant enzyme system to improve wheat performance under saline conditions. Plant Growth Regulation, vol. 69, no. 3, pp. 225-233. http://dx.doi. org/10.1007/s10725-012-9764-5.

Yasmeen, A., Nouman, W., Basra, S.M.A., Wahid, A., Rehman, H., Hussain, N. and Afzal, I., 2014. Morphological and physiological response of tomato (Solanumly copersicum L.) to natural and synthetic cytokinin sources: A comparative study. Acta Physiologiae Plantarum, vol. 36, no. 12, pp. 3147-3155. http://dx.doi.org/10.1007/s11738-014-1662-1.

Zhao, D. and Oosterhuis, D.M., 2000. Cotton responses to shade at different growth stages: Growth, lint yield and fiber quality. Experimental Agriculture, vol. 36, no. 1, pp. 27-39. http://dx.doi. org/10.1017/S0014479700361014. 